\title{
ORGANIC C DYNAMICS IN GRASSLAND SOILS. 2. MODEL VALIDATION AND SIMULATION OF THE LONG-TERM EFFECTS OF CULTIVATION AND RAINFALL EROSION'
}

\author{
R. P. VORONEY ${ }^{2}$, J. A. VAN VEEN ${ }^{3}$, and E. A. PAUL ${ }^{4}$
}

${ }^{2}$ Institute for Atomic Science, Wageningen. The Netherlands; 'Department of Soil Science, University of Saskatchewan, Saskatoon, Sask. S7N owo; and ${ }^{4}$ Department of Plant and Soil Biology, University of California, Berkeley, Calif. 9472.

Voroney, R. P., Van Veen, J. A. And Paul, E. A. 1981. Organic C dynamics in grassland soils. 2. Model validation and simulation of long-term effects of cultivation and rainfall erosion. Can. J. Soil Sci. 61: 211-224.

The amounts of organic matter in native prairie and in an adjacent cultivated field were compared with the output from a simulation model describing organic matter dynamics. The effects of past and possible future soil management practices, and the loss of organic $\mathrm{C}$ through rainfall erosion were incorporated into the simulation study. Seventy years of cultivation increased the bulk density of the A horizon by an average of $16 \%$ along the catena of a Black Chernozemic soil. Organic $\mathrm{C}$ had decreased by $36 \%$ in the soil profile at the mid-slope position. Losses of organic $\mathrm{N}$ were $5-10 \%$ less. Depletion of organic $\mathrm{C}$ and $\mathrm{N}$ from the Ah horizon accounted for $>90 \%$ of the total loss from the soil profile. Therefore, extrapolation of data from surface soil, based solely on changes in the concentration of organic $\mathrm{C}$ and $\mathrm{N}$, could result in an overestimation of organic matter losses from soils. Microbial biomass in the Ap horizon of the crop-summer-fallow site was $30 \%$ less than in the $\mathrm{Ah}$ horizon of the native prairie. The model predicted an immediate rise in microbial biomass $\mathrm{C}$ upon cultivation of the native prairie due to a large initial input of grassland litter and roots. Subsequently, the microbial biomass $\mathrm{C}$ decreased and approached a steady-state level which was $25 \%$ less than in the native prairie. The model indicates that large quantities of $\mathrm{N}$ released during the initial years of cultivation would not have been totally utilized by the cultivated crops, therefore resulting in major losses to the environment. However, now the organic matter is reaching a steady-state level and only small net release of $\mathrm{N}$ can be expected; external $\mathrm{N}$ sources are required for optimum crop production. Management practices such as straw removal and cropping sequence have short-term effects on the rate of depletion of soil organic C. Similar equilibrium levels of soil organic matter were predicted after $100 \mathrm{yr}$ of cultivation in simulation studies that did not consider erosion losses. The inclusion of rainfall erosion losses indicated that major organic $\mathrm{C}$ and other nutrient losses will occur in management practices that include significant portions of fallow in the cropping sequence.

Les quantités de matière organique (MO) dans un sol sous prairie originelle et dans un sol voisin sous culture ont ćté comparées avec les données modélisées relatives aux mécanismes de transformation de la MO. Le modèle mathématique prenait en compte les effets des pratiques agronomiques antérieures et éventuelles (futures), ainsi que les déperditions de $\mathrm{C}$ dues à l'érosion pluviale. Après 70 années de culture, la densité apparente de l'horizon A s'est accrue de $16 \%$ en moyenne tout au long de la chaîne

'Presented at the C.S.S.S. Symposium entitled "Long-term effects of intensive cultivation on soil quality, " Halifax. 1979.

Can J. Soil Sci. 61: 211-224 (May 1981) 
(caténa) d'un chernozem noir. A mi-pente, la teneur en $\mathrm{C}$ organique avait diminué de $36 \%$. Les pertes de Norganique étaient de 5 à $10 \%$ moindres. Les déperditions de Cet de $\mathrm{N}$ organiques de l'horizon Ah représentaient plus de $90 \%$ des pertes totales du profil entier, de sorte qu'une extrapolation des données du sol de surface basće exclusivement sur l'évolution des concentrations de $\mathrm{C}$ et de $\mathrm{N}$ organiques pourrait donner lieu à une surestimation des pertes de MO du sol. La biomasse microbienne de l'horizon Ap du champ exploité en alternance culture-jachère était $30 \%$ moins abondante que dans l'horizon Ah du sol sous prairie originelle. Le modèle a permis de prédire un accroissement immédiat du C microbien sous l'effet de la mise en culture de la prairie par suite de la forte incorporation initiale de litière et de racines d'herbe. Par la suite, le C microbien a diminué pour se stabiliser à un niveau $25 \%$ inférieur à celui de la prairie d'origine. Le modèle révèle que les abondantes quantités de $\mathrm{N}$ libérées dans les premières années de culture ne sont pas entièrement utilisées et qu'il s'en perd donc beaucoup à l'environnement immédiat. Cependant, à présent, la teneur en MO de ces sols arrive à un niveau d'équilibre, de sorte que les quantités de $\mathrm{N}$ libérées dans le sol sont relativement peu importantes et que par conséquent la fumure azotée s'impose si on veut réaliser des productions végétales optimales. Les pratiques agronomiques comme l'enlèvement des pailles et les assolements n'ont que des effets de courte durée sur le taux de déperdition du C organique. Des niveaux d'équilibre semblables de MO ont été prédits après 100 ans de mise en culture dans des études de modélisation ne tenant pas compte des pertes dues à l'érosion. L'inclusion des pertes dues à l'érosion causée par la pluie laisse à penser que d'importantes pertes de $C$ organique et d'autres nutriments risquent de se produire dans des systèmes culturaux accordant une place importante à la jachère.

Prairie soils have accumulated large amounts of organic matter under the native prairie ecosystem. Dryland cropping, consisting primarily of cereals and fallow in rotation, has resulted in a substantial decrease in soil organic C and N (Lipman and Blair 1921; Newton et al. 1945; Shutt 1925). Greenland (1962) reported that organic $N$ in the surface of some Australian soils had decreased by up to $50 \%$ after cultivation. Similar losses of organic matter have been recorded by Saunder and Grant (1962) for cultivated Rhodesian soils when compared to indigenous grass cover. In Western Canada, after 60-80 yr of cultivation, the concentration of organic $\mathrm{C}$ has decreased by $50-60 \%$ and the organic $\mathrm{N}$ by $40-50 \%$ in the Ap horizon of Chernozemic soils (Campbell et al. 1976).

The depletion of organic $\mathrm{C}$ and $\mathrm{N}$ with cultivation can be attributed to changes in the magnitude of biological and physical processes in soil. The rate of decomposition of soil organic matter increases during cultivation due to increased microbial activity under a more favorable soil moisture and temperature regime (MacDonald et al. 1973). Incorporation of plant residues and pulverization caused by the tillage operations would increase the rate of mineralization (Rovira and Greacen 1975). Reduced rates of C input to the soil, particularly root residues and exudates, have also influenced the rate of depletion (Paul and Van Veen 1978). Soil erosion during rainfall (Smith and Wischmeier 1962; Van Vliet and Wall 1979) and snowmelt (Nicholaichuk and Read 1978) have contributed to the depletion of organic matter from hillslopes. Wind erosion has seriously reduced the level of organic matter on both flat and undulating topography (Chepil and Woodruff 1963; Moss 1935).

Most of the previous studies of soil organic matter levels have only considered the concentration of organic $\mathrm{C}$ and $\mathrm{N}$ in the surface soil (Schlesinger 1979). In this study the amount of soil organic $\mathrm{C}$ and $\mathrm{N}$ and the soil bulk density were measured in the profile to the $\mathrm{Ck}$ horizon in similar catenas on a native prairie and cultivated field. These measurements were compared with the organic $\mathrm{C}$ level predicted by the organic matter model developed by Van Veen and Paul (1981). This model, which was developed for a Brown Chernozemic soil (Aridic Boroll), 
was validated with data obtained from a Black Chernozemic soil (Udic Boroll). The model was modified by incorporating the universal soil loss equation and was used to examine the effects of rainfall erosion and soil management practices on the rate of organic matter depletion.

\section{MATERIALS AND METHODS}

Samples were obtained from an Oxbow loam, a Black Chernozem developed on a mediumtextured, moderately calcareous unsorted glacial till (Head 1975). The land form consisted of knolls and depressions. Sampling sites were selected on a uniform, 100-m long slope with a $4 \%$ gradient and a northeast aspect on native prairie and an adjacent crop-summer-fallow field. The catena at the native prairie site ranged from an orthic profile at the upper and mid-slope to an eluviated profile at the lower slope (Table 1). The soil catena at the cultivated site had undergone similar pedogenic development (Table 2).

\section{History of Sampling Sites}

The dominant faciation of the native prairic site consisted of fescue grass, Festuca scabrella Torr. and woodlands (aspen poplar, Populas tremuloides Michx. and balsam poplar. Populas balsamifera L.). The cultivated site has been continuously cropped to cereals in 2- and 3-yr grain-summerfallow rotations since 1910 .

\section{Soil Analysis}

Triplicate soil cores $6.65 \mathrm{~cm}$ in diameter and 100 $\mathrm{cm}$ deep were obtained at the upper). mid-, and lower-slope positions of each study site. Bulk samples from the A and B horizons were sieved through a 20-mesh sieve to remove plant residues and maintained at about $100 \mathrm{kPA}$ ( 1 bar) moisture potential and $22^{\circ} \mathrm{C}$ for microbial biomass determination.

Organic $\mathrm{C}$ was determined by a wet dichromate oxidation technique slightly modified from Nelson and Sommers (1975) and organic N was determined by semimicro-Kjeldahl (Johns 1971). The chloroform fumigation-incubation technique (Jenkinson and Powlson 1976: Paul and Voroney 1980) was used to determine microbial biomass $C$ and $\mathrm{N}$.

\section{Model Inputs}

Organic MATTER levels. Radiocarbon dating of the organic matter fractions obtained after acid hydrolysis of an Oxbow soil has shown that $45 \%$ of the organic $\mathrm{C}$ was hydrolyzable and modern and $55 \%$ was old (equivalent age $\geqslant 500 \mathrm{yr}$ ) (Martel and Paul 1974). On this basis, $45 \%$ of the soil organic matter was assigned to the decomposable fraction and $55 \%$ was considered to be recalcitrant.

Decomposition studies have shown that the products of microbial metabolism were stabilized by chemical and physical mechanisms in the soil and therefore were partially protected against decomposition (Sørensen 1975; Van Veen and Paul (1981). This was included in the model by dividing both the decomposable and recalcitrant soil organic matter into protected and non-protected subfractions. The decomposition rate constant of protected organic matter was $1 / 100$ of the decomposition rate constant of the non-protected.

The study was started by simulating organic $\mathrm{C}$ dynamics under native prairie conditions. The initial levels of $\mathrm{C}$ in the organic matter fractions corresponded to data from the mid-slope position at the native prairie site (Table I). The protected and non-protected subfractions of decomposable and recalcitrant organic matter were arbitrarily set to equal levels. Annual input rates of $\mathrm{C}$ as litter/ plant residues and roots in the native prairie and under cultivation and their distribution within the soil profile are shown in Tables 3 and 4.

The flow of microbial products was directed in equal proportions $(0.5: 0.5)$ between the protected and non-protected subfactions under native prairie conditions. Under cultivation. it was assumed that these proportions changed to $0.2: 0.8$ in the surface soil and to 0.4:0.6 in the two layers for both the decomposable and recalcitrant organic matter (Van Veen and Paul 1981).

abiotic variables. Moisture tension and temperature data for the surface of a cultivated Oxbow soil are shown in Fig. 1. Averages of $10 \mathrm{yr}$ of rainfall and surface soil temperature data were obtained from records at the Indian Head Experimental Farm. Moisture content of the surface soil and for lower depths in the profile for both cropped and fallow conditions were predicted with the versatile soil moisture budget model (Baier et al. 1972). Soil temperaturc at lower profile depths was assumed to be proportional to that at the surface. Reduction factors of 0.8 and 0.6 of the surface soil temperature were used to calculate temperature for the second and third layers, respectively.

SOIl ERosion. Rainfall-induced erosion from 
Table 1. Bulk density and organic $\mathrm{C}$ and $\mathrm{N}$ levels along a catena at the native prairie site

\begin{tabular}{|c|c|c|c|c|}
\hline \multirow[b]{2}{*}{ Soil horizon } & \multirow{2}{*}{$\begin{array}{l}\text { Depth } \\
(\mathrm{cm})\end{array}$} & \multirow{2}{*}{$\begin{array}{c}\text { Bulk density } \\
\left(\mathrm{g} \cdot \mathrm{cm}^{-3}\right)\end{array}$} & \multicolumn{2}{|c|}{$\begin{array}{l}\text { Organic matter level } \\
\text { (thousand } \mathrm{kg} \cdot \mathrm{ha}^{-1} \text { ) }\end{array}$} \\
\hline & & & $\mathrm{C}$ & $\mathrm{N}$ \\
\hline $\begin{array}{l}\mathrm{Ah} \\
\mathrm{Bm} \\
\mathrm{Cca} \\
\mathrm{Ck}_{1}\end{array}$ & $\begin{array}{l}0-12 \pm 2.51(1 \div) \\
-25 \pm 2.1 a \\
-51 \pm 1.8 \\
-71\end{array}$ & $\begin{array}{l}\text { Upper slope } \\
0.93 \pm 0.08(1) \\
1.35 \pm 0.07 a(2) \\
1.49 \pm 0.05 b(3) \\
1.51 \pm 0.08\end{array}$ & $\begin{array}{l}63.61 \pm 9.2 \\
30.59 \\
21.87 \\
4.08 \\
\end{array}$ & $\begin{array}{l}4.79 \pm 0.8 \\
3.04 \\
2.15 \\
0.36 \\
\end{array}$ \\
\hline Pedon & & Mid-slope & $\overline{120.15}$ & 10.34 \\
\hline $\begin{array}{l}\mathrm{Ah} \\
\mathrm{Bm} \\
\mathrm{Cca} \\
\mathrm{Ck}_{1}\end{array}$ & $\begin{array}{l}0-15 \pm 1.3 \\
-39 \pm 6.0 \\
-59 \pm 5.1 \\
-69\end{array}$ & $\begin{array}{l}1.11 \pm 0.06(1) \\
1.37 \pm 0.08 a(2) \\
1.47 \pm 0.04 b(3) \\
1.49 \pm 0.05\end{array}$ & $\begin{array}{l}94.14 \pm 6.0 \\
37.98 \\
16.17 \\
3.87 \\
\end{array}$ & $\begin{array}{l}7.29 \pm 0.5 \\
3.70 \\
1.62 \\
0.42 \\
\end{array}$ \\
\hline Pedon & & Lover slope & $\overline{152.16}$ & 13.03 \\
\hline $\begin{array}{l}\text { Ah } \\
\text { Ahe } \\
\mathrm{Bt} \\
\mathrm{Cca} \\
\mathrm{Ck}_{1}\end{array}$ & $\begin{array}{l}0-13 \pm 0.5 \\
-24 \pm 1.0 \\
-47 \pm 1.3 \\
-71 \pm 1.3 \\
-81\end{array}$ & $\begin{array}{l}1.06 \pm 0.07(1) \\
1.28 \pm 0.02 \\
1.48 \pm 0.04 \\
1.59 \pm 0.09 a(3) \\
1.53 \pm 0.04\end{array}$ & $\begin{array}{l}83.29 \pm 6.2 \\
27.03 \\
26.02 \\
10.69 \\
4.28 \\
\end{array}$ & $\begin{array}{l}6.45 \pm 0.2 \\
2.38 \\
3.68 \\
1.07 \\
0.46 \\
\end{array}$ \\
\hline Pedon & & & 162.11 & $\overline{14.04}$ \\
\hline
\end{tabular}

$\uparrow$ Numbers denote no significant difference $(P<0.05)$ between slope positions within a study site using Scheffe's test (1959).

$a, b$ Lower case letters denote no significant difference $(P<0.05)$ between the study sites using Scheffe's test (1959)

Table 2. Bulk density and organic $\mathrm{C}$ and $\mathrm{N}$ levels along a catena at the crop-summer-fallow site

\begin{tabular}{|c|c|c|c|c|}
\hline \multirow[b]{2}{*}{ Soil horizon } & \multirow{2}{*}{$\begin{array}{c}\text { Depth } \\
(\mathrm{cm})\end{array}$} & \multirow{2}{*}{$\begin{array}{l}\text { Bulk density } \\
\left(\mathrm{g} \cdot \mathrm{cm}^{-3}\right)\end{array}$} & \multicolumn{2}{|c|}{$\begin{array}{l}\text { Organic matter level } \\
\text { (thousand } \mathrm{kg} \cdot \mathrm{ha}^{-1} \text { ) }\end{array}$} \\
\hline & & & C & $\mathrm{N}$ \\
\hline $\begin{array}{l}\mathrm{Ap} \\
\mathrm{Bmk} \\
\mathrm{Cca} \\
\mathrm{Ck}_{1}\end{array}$ & $\begin{array}{l}0-9 \pm 0.9 \\
-25 \pm 2.4 a \\
-39 \pm 1.4 \\
-49\end{array}$ & $\begin{array}{l}\text { Upper slope } \\
1.15 \pm 0.06(1) \\
1.30 \pm 0.30 a \\
1.42 \pm 0.06 b \\
1.45 \pm 0.06\end{array}$ & $\begin{array}{l}26.44 \pm 2.67 a \\
30.13 \\
9.91 \\
3.91 \\
\end{array}$ & $\begin{array}{l}2.61 \pm 0.23 a \\
3.01 \\
0.91 \\
0.36 \\
\end{array}$ \\
\hline Pedon & & Mid-slope & $\overline{70.39}$ & 6.89 \\
\hline $\begin{array}{l}\text { Ap } \\
\text { Bm } \\
\text { Bmk } \\
\text { Cca } \\
\mathrm{Ck}_{1}\end{array}$ & $\begin{array}{l}0-13 \pm 1.3 a(1 \dagger) \\
-34 \pm 1.5 \\
-44 \pm 1.4 b \\
-61 \pm 1.3 c \\
-71\end{array}$ & $\begin{array}{l}1.17 \pm 0.04(1) \\
1.38 \pm 0.09 a \\
1.41 \pm 0.04 \\
1.51 \pm 0.07 b(2) \\
1.56 \pm 0.06\end{array}$ & $\begin{array}{l}40.15 \pm 3.07 a \\
29.78 \\
10.72 \\
12.76 \\
3.28 \\
\end{array}$ & $\begin{array}{l}3.64 \pm 0.34 a \\
2.78 \\
1.07 \\
1.28 \\
0.31 \\
\end{array}$ \\
\hline Pedon & & Lower slope & $\overline{96.69}$ & 9.08 \\
\hline $\begin{array}{l}\mathrm{Ap} \\
\mathrm{Ahe} \\
\mathrm{Bt} \\
\mathrm{Cca} \\
\mathrm{Ck}_{1}\end{array}$ & $\begin{array}{l}0-13 \pm 0.8 a(1) \\
-22 \pm 1.5 \\
-39 \pm 1.0 \\
-47 \pm 1.0 \\
-57\end{array}$ & $\begin{array}{l}1.21 \pm 0.06(1) \\
1.32 \pm 0.04 \\
1.47 \pm 0.02 \\
1.57 \pm 0.08 a(2) \\
1.53 \pm 0.07\end{array}$ & $\begin{array}{l}49.24 \pm 3.73 a \\
19.29 \\
28.49 \\
3.96 \\
2.91 \\
\end{array}$ & $\begin{array}{l}4.52 \pm 0.49 a \\
1.87 \\
2.62 \\
0.41 \\
0.26 \\
\end{array}$ \\
\hline Pedon & & & 103.89 & 9.68 \\
\hline
\end{tabular}

$\dagger$ Numbers denote no significant difference $(P<0.05)$ between slope positions within a study site using Scheffe's test (1959).

$a, b$ Lower case letters denote no significant difference $(P<0.05)$ between the study sites using Scheffe's test $(1959)$. 
Table 3. Annual input rates of $\mathrm{C}$ from litter/plant residues and roots in the native prairie $\frac{1}{t}$ and under cultivation for an Oxbow soil

\begin{tabular}{lcc}
\hline \hline & $\begin{array}{c}\text { Litter/plant } \\
\text { residues }\end{array}$ & Roots \\
\hline & $\mathrm{kg} \mathrm{C} \cdot \mathrm{ha}^{-1} \cdot \mathrm{yr}^{-1}-$ \\
Native prairie & 1300 & 1800 \\
Continuous cropping & 1226 & 690 \\
Crop-fallow rotation & & \\
$\quad$ Crop & 1520 & 856 \\
$\quad$ Fallow & 152 & 86 \\
Crop-crop-fallow rotation & & \\
$\quad$ Crop & 1520 & 856 \\
Crop & 1234 & 690 \\
Fallow & 138 & 77 \\
\hline
\end{tabular}

†xtrapolated from Matador (I.B.P.) data. †Adapted from Halstead (1978).

Table 4. Distribution of the annual input of $\mathrm{C}$ within the soil profile

\begin{tabular}{lcccccc}
\hline \hline & \multicolumn{2}{c}{ Native prairiet } & & \multicolumn{2}{c}{ Cultivated soilst } \\
\cline { 2 - 3 } \cline { 5 - 6 } $\begin{array}{l}\text { Depth } \\
\text { (cm) }\end{array}$ & $\begin{array}{c}\text { Root- } \\
\text { C }\end{array}$ & $\begin{array}{c}\text { Litter- } \\
\text { C }\end{array}$ & & $\begin{array}{c}\text { Root- } \\
\text { C }\end{array}$ & $\begin{array}{c}\text { Crop } \\
\text { residue-C }\end{array}$ \\
\hline & & & $\%$ & & \\
\cline { 6 - 7 } $0-15$ & 62 & 80 & & 50 & 80 \\
$15-40$ & 18 & 20 & & 26 & 20 \\
$40-80$ & 20 & 0 & & 24 & 0 \\
\hline
\end{tabular}

$\uparrow$ Adapted from Coupland and Brayshaw (1953).

†Campbell et al. (1977).

the surface horizon of the cultivated field was predicted by incorporating the universal soil loss equation (Wischmeier and Smith 1961) into the model. This equation groups six major erosion factors to estimate average annual soil loss. The equation is:

$$
A=R \cdot K \cdot L \cdot S \cdot C \cdot P
$$

where $A$ is the average soil loss from a field with defined soil physical and chemical properties, length and degree of slope. cropping management plan and erosion conservation practices

The $R$ factor is a measure of the erosive forces of rainfall and runoff over a season. An $R$ factor equal to 35 (the $R$ factor was determined by G. Kachanoski, Department of Soil Science, University of Saskatchewan, Saskatoon, Sask.) was determined from 2 yr of rainfall data for this study site. Runoff from snowmelt was not included in this evaluation.

The $K$ factor is highly correlated to soil particle size distribution, organic matter content, structure and permeability (Wischmeier et al. 1971). Values for $K$ were determined assuming that the Ap horizon had a medium granular structure and moderate permeability utilizing the soil erodibility nomograph described by Wischmeicr et al. (1971). The $K$ factor was set to 0.8 when the organic matter content was 0 and decreased linearly to 0 when the organic matter content was $\geqslant 7 \%$.

$L$ and $S$ are dimensionless factors that adjust the soil loss estimate for effects of length, steepness, and shape of the field slope. The $L \cdot S$ value at the study site was 0.55 , using the equation described by Wischmeier and Smith (1965).

The $C$ factor is evaluated for each different cropping sequence. Values for $C$ were 0.003 for continuous grasses, 0.16 for continuous cropping and 0.24 for a crop-summer-fallow rotation (Wischmeier and Smith 1961).

The $P$ factor considers the preventive measures used to control erosion compared to erosion losses from a bare fallowed field. Values for $P$, estimated from data presented by Smith and Wischmeier (1962), were 0.3 for the continuous cropping conditions and 0.75 for the crop-summer-fallow rotation.

Soil loss, $A$, is expressed in tons of soil per acre per year. Organic $C$ loss (tons $C \cdot$ acre $^{-1} \cdot \mathrm{yr}^{-1}$ ) was calculated by multiplying the predicted soil organic $\mathrm{C}$ content (\%) by the quantity of eroded soil.

\section{RESULTS \\ Organic Matter Levels}

FiEld daTA. Comparisons of the amount of soil organic matter present in native prairie grasslands with that in corresponding cultivated fields have generally involved measuring the changes in concentration $(\%)$ of organic $\mathrm{C}$ and $\mathrm{N}$ in samples obtained from an arbitrary depth (Doughty et al. 1954; Newton et al. 1945). However, cultivation increases the bulk density of the surface soil which affects this comparison. Cultivation increased the bulk density of the surface soil at the three slope positions by $16 \%$, from 1.03 (Table 1) to $1.19 \mathrm{~g} \cdot \mathrm{cm}^{-1}$ (Table 2). If the native prairie and cultivated sites were sampled to the same depth, the samples from the cultivated site may contain more soil. Also, the surface soil could have been mixed with soil from depth during cultivation. These factors could lower the concentration of the organic $\mathrm{C}$ and $\mathrm{N}$ in a surface soil sample from a cultivated field. However, these sampling 


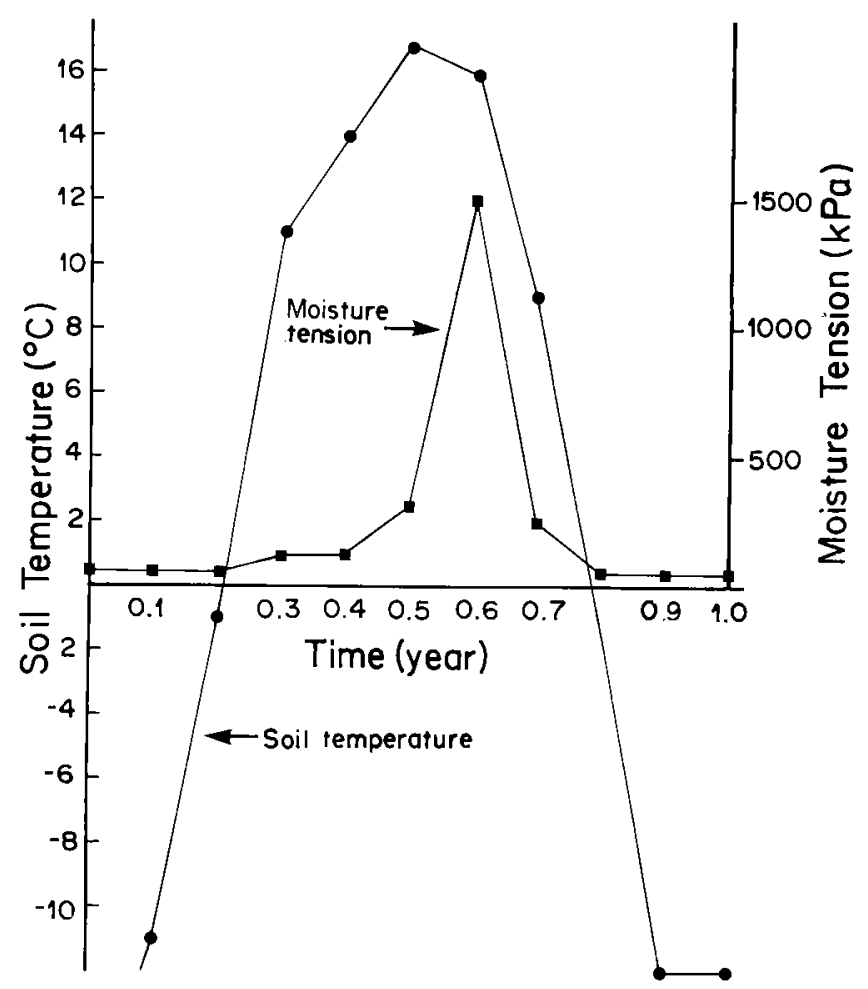

Fig. 1. Soil temperature and moisture tension in the surface $15 \mathrm{~cm}$ of a cultivated Oxbow soil.

errors were avoided by sampling the complete profile.

The amount of organic $C$ in the soil pedon of the native prairie site ranged from 120000 $\mathrm{kg} \cdot \mathrm{ha}^{-1}$ at the upper-slope position to $162000 \mathrm{~kg} \cdot \mathrm{ha}^{-1}$ at the lower-slope position (Table 1). In the cultivated site the amount ranged from 58 to $64 \%$ of that in the native prairie site (Tables 1 and 2). The organic $\mathrm{N}$ level ranged from 10300 to $14000 \mathrm{~kg} \cdot \mathrm{ha}^{-1}$ for the native prairie site and decreased to $65-69 \%$ of these levels in the cultivated site. At the mid-slope position the amount of organic $\mathrm{C}$ in the pedon decreased by $36 \%$. from 152000 to $96000 \mathrm{~kg} \cdot \mathrm{ha}^{-1}$. due to cultivation; the organic $\mathrm{N}$ level decreased by $30 \%$. This is a much lower rate of loss of organic matter than previously reported (Campbell et al. 1976).

The Ah horizon at the mid-slope position lost $58 \%$ of its organic $\mathrm{C}$ and $50 \%$ of its $\mathrm{N}$ in $70 \mathrm{yr}$ of cultivation (Tables 1 and 2). The decrease from the Ah horizon accounted for $>90 \%$ of the total losses of organic C andN from the soil profile. Loss of organic matter at the upper-slope position was greater than at the lower-slope position which indicated that soil erosion had a marked affect on the loss of organic matter from hillslopes.

Simulation trials. The simulation of organic $\mathbf{C}$ dynamics in the native prairie showed that the organic $C$ content of the pedon approached an equilibrium level similar to that determined experimentally. During simulation, the sizes of the subfractions of the decomposable soil organic matter changed from the initial equal levels to $90 \%$ protected and $10 \%$ non-protected. The predicted equilibrium levels of organic matter under native 
prairie conditions were used as initial values for the simulation of organic matter dynamics during cultivation (Table 5).

The model accurately predicted the organic $\mathrm{C}$ level in the soil pedon after $70 \mathrm{yr}$ of cultivation (Fig. 2 and Table 6). The main difference between the experimentally determined and the predicted level was that the model overestimated the loss of organic $\mathrm{C}$ in the second and third layers. One explanation might be that the assumed decrease in the proportion of microbial products entering the protected subfraction, i.e., from 0.5 in the native prairie to 0.4 in the cultivated soil, for the 15 to 40-cm layer (Van Veen and Paul 1981) was not appropriate for a Black soil.

The model predicted that the soil organic matter should approach a steady state at approximately $60 \%$ of its original level after about $100 \mathrm{yr}$ of cultivation (Fig. 3). The different cereal rotations considered in this study did not significantly alter the steady-state organic $\mathrm{C}$ level is organic matter turnover alone was considered.

\section{Microbial Biomass Levels}

FiELD DATA. The level of soil microbial biomass reflects the rate of addition of plant residue to soil (Jenkinson and Powlson 1976). Microbial biomass was higher in: the native prairie soil compared to the cultivated soil; the surface horizon compared to the $\mathrm{B}$ horizon; and the lower-slope soil compared to the upper-slope soil.

The Ah horizon at the mid-slope position of the native prairie site had a microbial biomass of $1472 \mathrm{~kg} \mathrm{C}$ and $311 \mathrm{~kg} \mathrm{~N} \cdot \mathrm{ha}^{-1}$ (Table 7). The level of microbial biomass in the Ap horizon (mid-slope) of the cultivated site was $25-40 \%$ lower. The microbial biomass constituted an average of $2.5 \%$ of the soil organic $\mathrm{C}$ and $4.9 \%$ of the organic $\mathrm{N}$ and there was a tendency for this proportion to increase down the slope. Cropping increased the proportion of soil $\mathrm{C}$ and $\mathrm{N}$ constituted by biomass in the $\mathrm{A}$ horizon but decreased the proportion in the $\mathrm{B}$ horizon.

Simulation trials. The model was capable of assessing such physiological aspects as microbial growth, efficiency of $\mathrm{C}$ utilization for biosynthesis, and microbial decay. The measurements of microbial biomass in the native prairie and cultivated sites were used to validate this aspect of the model. The model predicted a microbial biomass of 1350 $\mathrm{kg} \mathrm{C} \cdot \mathrm{ha}^{-1}$ in the native prairie (Fig. 3). This value fluctuated by $100 \mathrm{~kg} \mathrm{C} \cdot \mathrm{ha}^{-1}$ due to seasonal variations in $\mathrm{C}$ input and climate.

The model predicted an immediate rise in microbial biomass $C$ upon cultivation of the native prairie in response to the large initial input of grassland litter and roots. Subsequently, the biomass decreased to about 1025

Table 5. The initial organic $\mathrm{C}$ levels $\ddagger$ for the various fractions of organic matter at the start of simulation of cultivation and their decomposition rate constants

\begin{tabular}{|c|c|c|c|c|}
\hline & \multicolumn{3}{|c|}{ Organic matter level $\left(\mathrm{kg} \mathrm{C} \cdot \mathrm{ha}^{-1}\right)$} & \multirow{3}{*}{$\begin{array}{l}\text { Decomposition } \\
\text { rate constant } \\
\left(\text { day }^{-1}\right)\end{array}$} \\
\hline & \multicolumn{3}{|c|}{ Depth $(\mathrm{cm})$} & \\
\hline & $0-15$ & $15-40$ & $40-80$ & \\
\hline Litter & 1000 & 300 & - & $8 \times 10^{-2}$ \\
\hline Roots & 6800 & 3000 & 3000 & $8 \times 10^{-2}$ \\
\hline Microbial biomass & 1350 & 1020 & 500 & $3 \times 10^{-2}$ \\
\hline \multicolumn{5}{|l|}{ Decomposible OM } \\
\hline Protecterl & 36000 & 14400 & 7200 & $8 \times 10^{-4}$ \\
\hline Non-pro ected & 4000 & 1600 & 800 & $8 \times 10^{-2}$ \\
\hline \multicolumn{5}{|l|}{ Recalcitrant OM } \\
\hline Protecterl & 22000 & 9000 & 5000 & $8 \times 10^{-8}$ \\
\hline Non-pro ected & 22000 & 9000 & 5000 & $8 \times 10^{-6}$ \\
\hline
\end{tabular}

These are the model outputs at steady state from simulation of native prairie conditions. 


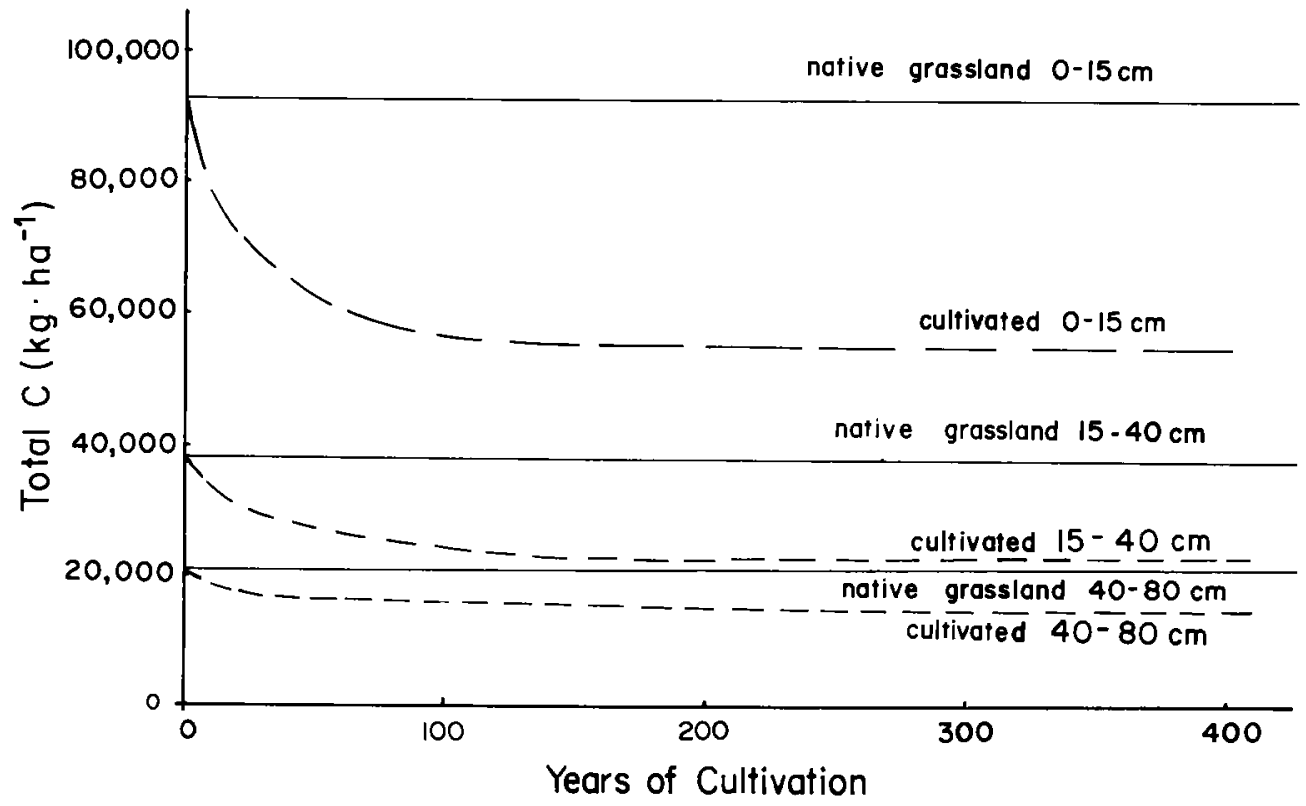

Fig. 2. Model output of the effect of cultivation (crop-crop-fallow rotation) on the level of organic $\mathrm{C}$ in the pedon of an Oxbow soil.

Table 6. Comparison of experimental data with predicted levels of organic C after simulation of $70 \mathrm{yr}$ of cultivation of an Oxbow soil

\begin{tabular}{|c|c|c|c|c|}
\hline \multirow{3}{*}{$\begin{array}{l}\text { Depth } \\
(\mathrm{cm})\end{array}$} & \multicolumn{4}{|c|}{ Decrease in organic $C$} \\
\hline & \multicolumn{2}{|c|}{$\mathrm{kg} \cdot \mathrm{ha}^{\mathrm{l}}$} & \multicolumn{2}{|l|}{$\%$} \\
\hline & Experimental & Model & Experimental & Model \\
\hline $0-15$ & 54000 & 51500 & 57 & 55 \\
\hline $15-40$ & 8200 & 11000 & 22 & 29 \\
\hline $40-80$ & 4000 & 4900 & 20 & 22 \\
\hline
\end{tabular}

$\mathrm{kg} \mathrm{C} \cdot \mathrm{ha}^{-1}$ after $70 \mathrm{yr}$ of cultivation, a decrease of $24 \%$ compared to the native prairie. Annual fluctuations in microbial biomass occurred under cultivated conditions; however, the predicted average level of microbial biomass under crop-summer-fallow and continuous cropping was similar.

\section{Soil Erosion}

The various cropping rotations tested did not greatly affect organic $C$ levels when rainfallinduced soil erosion effects were not included in the simulation study. However, simulation studies showed that erosion had a drastic effect on organic $\mathrm{C}$ levels especially after 50-80 yr of cultivation, resulting in a continual decline of organic matter content (Fig. 5). Present day rainfall-induced soil erosion losses from the cultivated site were estimated to be 1.7 tons $\cdot \mathrm{ha}^{-1} \cdot \mathrm{yr}^{-1}$ by the universal soil loss equation. (This estimate which was converted from the original tons per acre does not include losses due to snowmelt. Carolyn Hubbard, Department of Soil Science, Univ. of Saskatchewan, estimated total average soil losses of 2.3 tons $\cdot \mathrm{ha}^{-1} \cdot \mathrm{yr}^{-1}$ on the same site from data utilizing cesium counting techniques.)

Due to its higher concentration in the surface soil and its low density, organic matter is among the first constituents removed by erosion (Lucas et al. 1977). Allison (1973) reported that the eroded material was about five times richer in organic matter than the residual soil. Doubling the organic $\mathrm{C}$ content of eroded sediments resulted in a much faster 


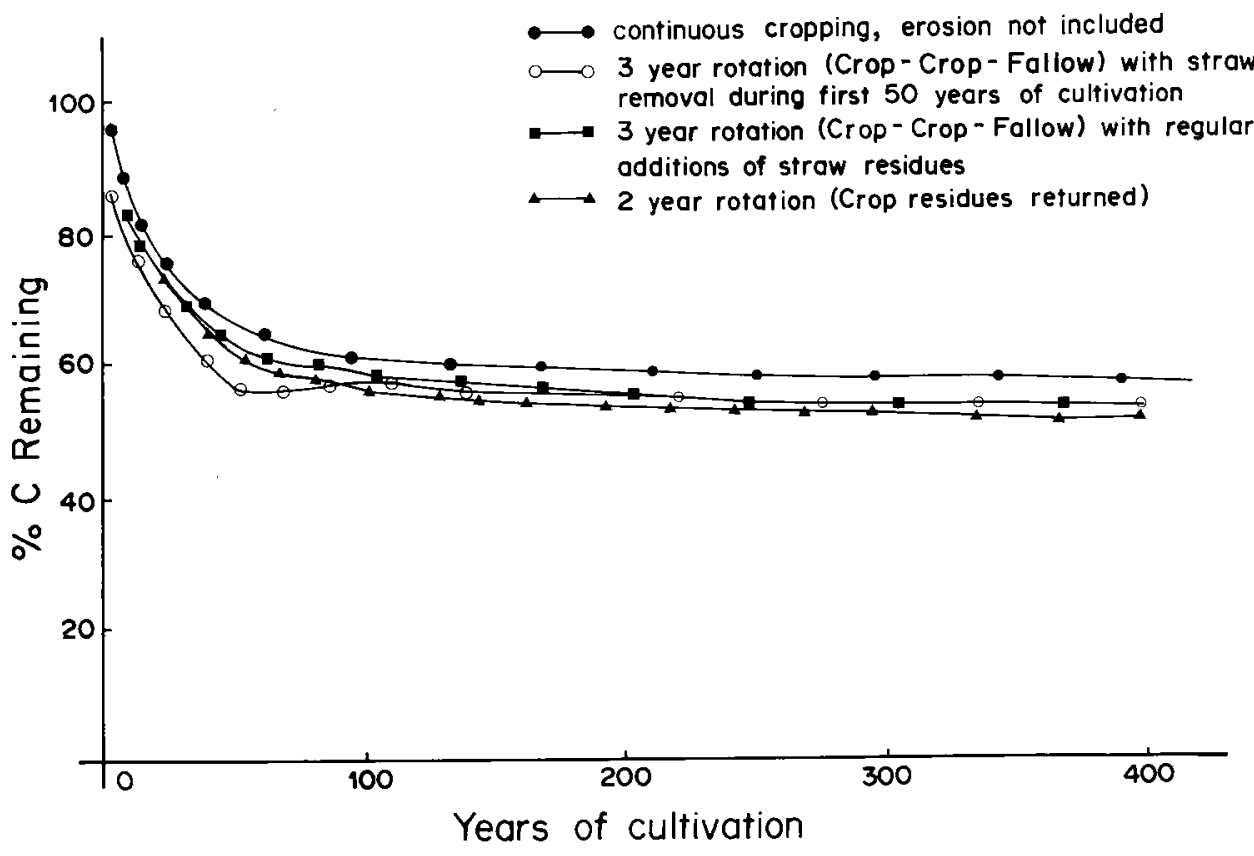

Fig. 3. Effect of various cereal rotations on the organic $\mathrm{C}$ remaining in the surface $15 \mathrm{~cm}$ as predicted by the organic matter model.

rate of organic $\mathrm{C}$ depletion (Fig. 5). Also, simulation showed that the rate of depletion of soil organic $\mathrm{C}$ can be drastically reduced by continuous cropping and by returning crop residues causing reduction in soil erosion (Fig. 5).

\section{DISCUSSION}

The rate of loss of organic $\mathrm{C}$ and $\mathrm{N}$ from native prairie soils has been shown to be most rapid during the first 5-10 yr after breaking and more gradual afterwards (Caldwell et al. 1939; Martel and Paul 1974). This initial decline could be partly due to the decomposition of grassland litter and roots. An equilibrium level of soil organic $\mathrm{C}$, proportional to the amount of residue $\mathrm{C}$ returned to the soil, will eventually be established (Sauerbeck and Gonzalez 1977). Lucas et al. (1977) predicted that equilibrium soil $\mathrm{C}$ levels will be reached $80-100$ yr after changing a crop rotation or soil management practice.
The experimental data indicated that 4000 $\mathrm{kg} \mathrm{N} \cdot \mathrm{ha}^{-1}$ were released during $70 \mathrm{yr}$ of cultivation. This model was not designed to estimate accurately the rate of release of mineral $\mathrm{N}$. Therefore, the annual production of mineral $\mathrm{N}$ was calculated from the decline of soil organic $\mathrm{C}$ content assuming fixed $\mathrm{C}: \mathrm{N}$ ratios for soil organic matter $(10: 1)$, microbial biomass $(8: 1)$, plant roots $(50: 1)$ and straw $(60: 1)$. During the initial years after cultivation, the amount of nitrogen released would greatly exceed the requirements of a growing crop (Table 8). However, at present the rate of net mineralization would be insufficient to meet the requirements of a cereal crop $(\sim 60$ $\left.\mathrm{kg} \mathrm{N} \cdot \mathrm{ha}^{-1} \cdot \mathrm{yr}^{-1}\right)$ on Black soils of Saskatchewan.

Nitrogen is removed from soil in the form of plant residue and harvested grain. It was estimated, based on data reported by Halstead (1978), that $70 \mathrm{yr}$ of cereal cropping to a crop-crop-fallow rotation would have yielded 


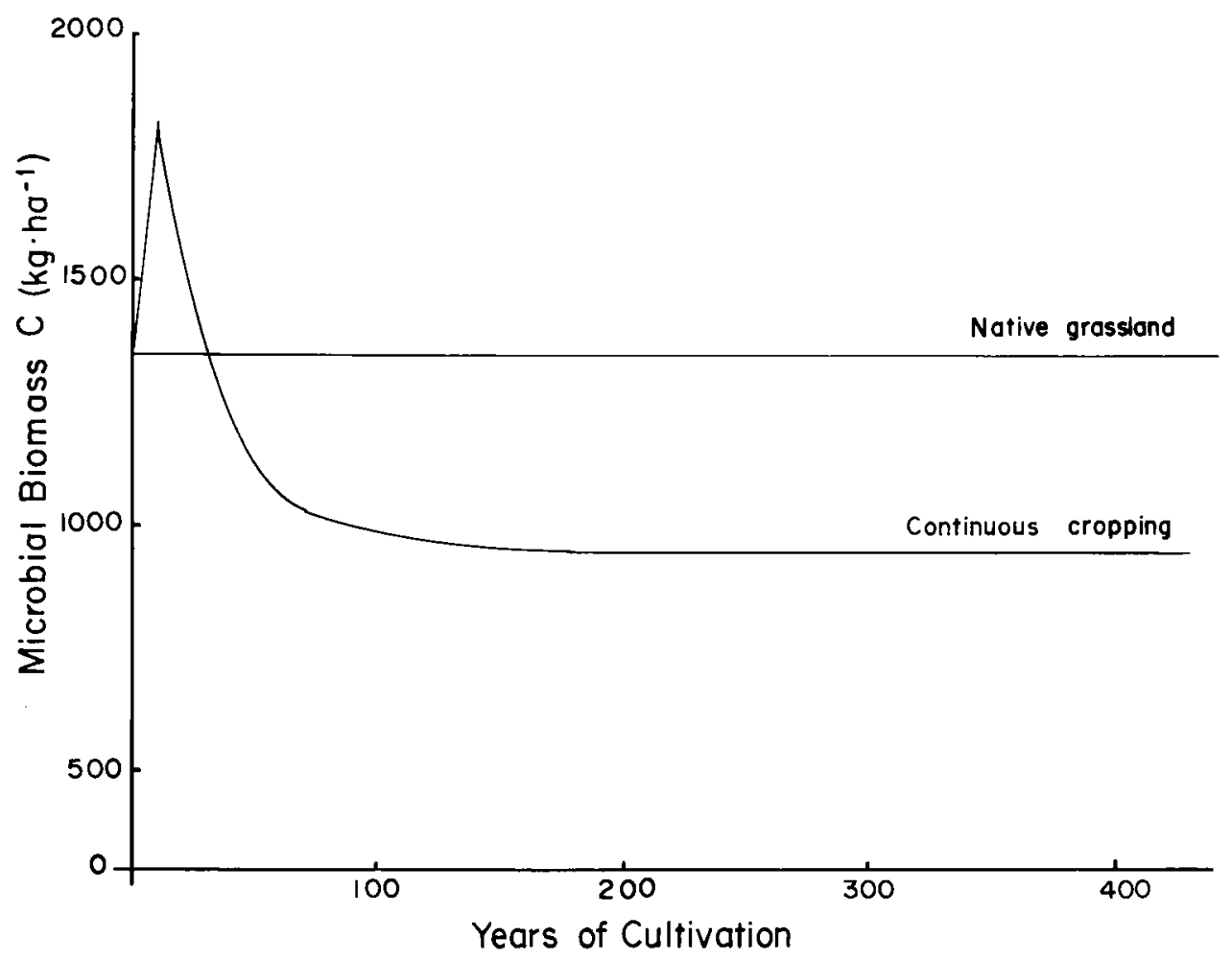

Fig. 4. Model output for the level of microbial biomass $\mathrm{C}$ in the native prairie and the cultivated soil.

$1300 \mathrm{~kg} \mathrm{~N} \cdot \mathrm{ha}^{-1}$ of grain and $300 \mathrm{~kg} \mathrm{~N} \cdot \mathrm{ha}^{-1}$ of straw residues. Grain N, therefore, would account for $33 \%$ of the $\mathrm{N}$ lost during cultivation. Removal of straw residues by burning, which results in a loss of $27-73 \%$ of its $\mathrm{N}$ (Biederbeck et al. 1980), or its use for other purposes would directly account for only 3-7.5\% of the depleted soil N. Movement with soil water, leaching below the rooting zone (Henry 1975; Meneley 1976) and denitrification (Chatarpaul et al. 1980; Cho et al. 1975) are probably responsible for the majority of the $\mathrm{N}$ lost after mineralization.

Snowmelt runoff accounts for $85 \%$ of the total runoff from agricultural watersheds in Western Canada (Nicholaichuk 1967). Snowmelt losses of soil sediments from hillslopes on Wood Mountain loam in the Brown soil zone in southwest Saskatchewan were $112 \mathrm{~kg} \cdot \mathrm{ha}^{-1} \cdot \mathrm{yr}^{-1}$ on stubble fields and 433 $\mathrm{kg} \cdot \mathrm{ha}^{-1} \cdot \mathrm{yr}^{-1}$ on bare fields (Nicholaichuk and Read 1978). The runoff also contained $0.5 \mathrm{~kg} \mathrm{~N} \cdot \mathrm{ha}^{-1} \cdot \mathrm{yr}^{-1}$ soluble $\mathrm{N}$ on stubble fields and $2.8 \mathrm{~kg} \mathrm{~N} \cdot \mathrm{ha}^{-1} \cdot \mathrm{yr}^{-1}$ on the bare fallowed fields. Losses of soluble nutrients are not predicted by the universal soil loss equation but would be an important component in the description of organic matter depletion in soils by water erosion (Barrows and Kilmer 1963).

The simulation studies have shown that continuous cropping and returning plant residues to soil, helps to maintain soil quality by reducing soil erosion. This is in agreement with recent reports of field observations of straw effects (Campbell et al. 1976). Burning has no significant effects on yields (Dormaar et al. 1979; Biederbeck et al. 1980), although yields tended to be greater when the straw was not burned (Dormaar et al. 1979). The 

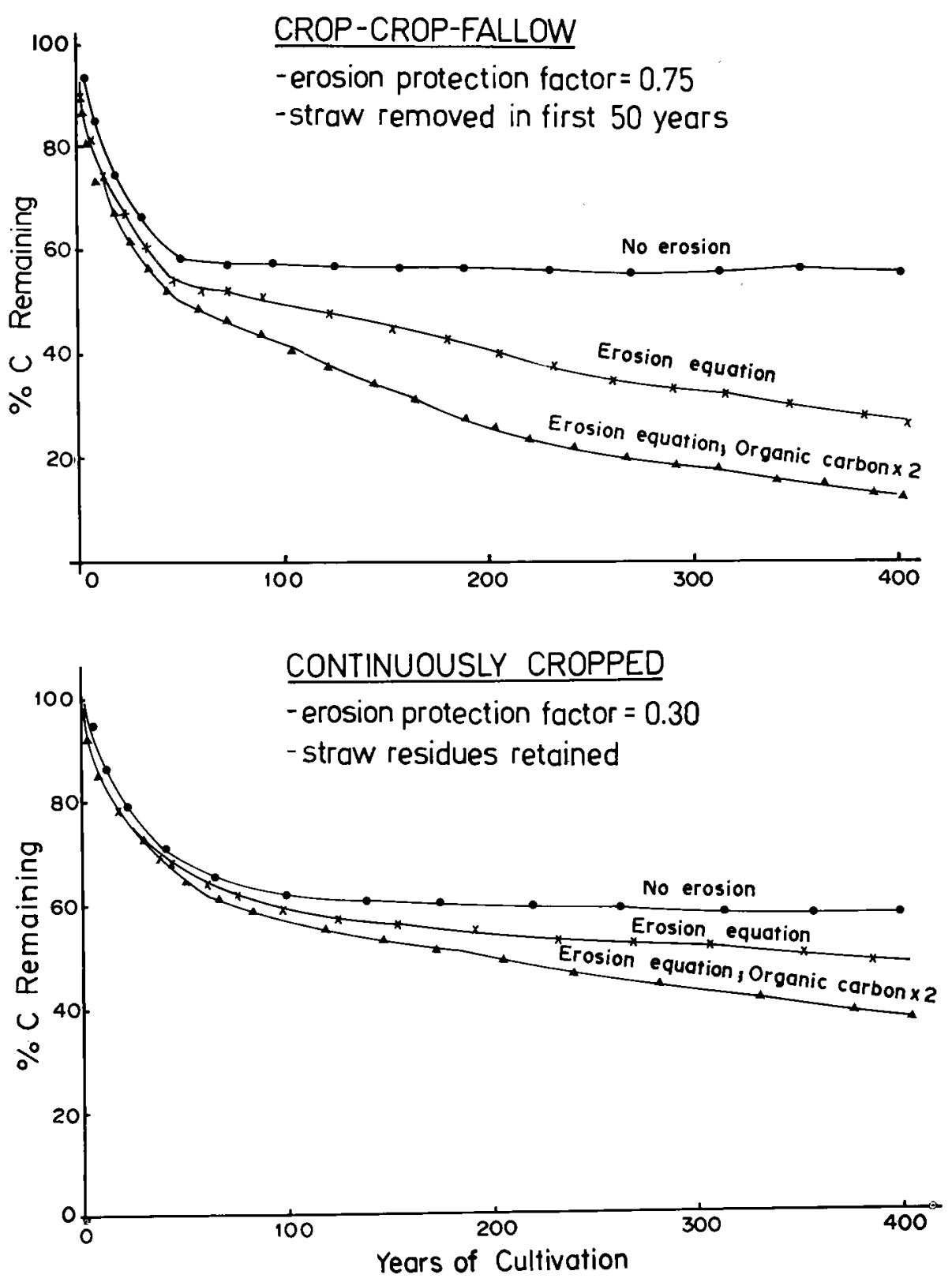

Fig. 5. Effect of rainfall-induced soil erosion, calculated by the universal soil loss equation, on the organic $\mathrm{C}$ remaining in the surface $15 \mathrm{~cm}$ of a cultivated Oxbow soil. 
Table 7. Microbial biomass $\mathrm{C}$ and $\mathrm{N}$ in incubated Oxbow soil $\uparrow$ obtained from a native prairie and a cultivated field

\begin{tabular}{|c|c|c|c|c|}
\hline & \multicolumn{4}{|c|}{ Microbial biomass } \\
\hline & \multicolumn{2}{|c|}{$\mathrm{kg} \cdot \mathrm{ha}^{-1}$} & \multicolumn{2}{|c|}{ Percent of soil organic matter } \\
\hline & $\mathrm{C}$ & $\mathrm{N}$ & $\mathrm{C}$ & $\mathrm{N}$ \\
\hline \multicolumn{5}{|c|}{ Native prairie } \\
\hline Upper-slope Ah & 767 & 149 & 1.2 & 3.1 \\
\hline Upper-slope Bm & 383 & 77 & 1.3 & 2.5 \\
\hline Mid-slope Ah & 1472 & 311 & 1.6 & 4.3 \\
\hline Mid-slope Bm & 1214 & 220 & 3.2 & 6.0 \\
\hline Lower-slope Ah/Ahe & 2829 & 605 & 2.6 & 6.9 \\
\hline Lower-slope Bt & 1504 & 292 & '4.1 & 7.9 \\
\hline \multicolumn{5}{|c|}{ Cultivated } \\
\hline Upper-slope Ap & 624 & 111 & 2.4 & 4.3 \\
\hline Upper-slope Bmk & 416 & 65 & 1.4 & 2.2 \\
\hline Mid-slope Ap & 1122 & 195 & 2.8 & 5.4 \\
\hline Mid-slope Bm & 727 & 135 & 2.4 & 4.9 \\
\hline Lower-slope Ap/Ahe & 2240 & 360 & 3.3 & 5.6 \\
\hline Lower-slope Bt & 917 & 157 & 3.2 & 6.0 \\
\hline
\end{tabular}

Soil was passed through a 20 -mesh sieve in a moist state and incubated at $22^{\circ} \mathrm{C}$ for 3 mo before biomass was measured.

$\Varangle$ Microbial biomass was measured by the chloroform fumigation-incubation technique $\left(K_{\mathrm{c}}=0.4 \mathrm{I} 1\right.$ and $\left.K_{\mathrm{N}}=0.28\right)$ (Paul and Voroney 1980).

beneficial physical effects of soil organic matter on crop yields as compared with the nutrients released from the mineralization of soil organic matter is an important feedback mechanism in organic matter turnover (Lucas et al. 1977). Lower soil organic matter levels usually result in lower crop yields, therefore

Table 8. Predicted annual rate of $\mathrm{N}$ mineralization in an Oxbow soilt + during cultivation

\begin{tabular}{lrrrr}
\hline \hline \multirow{2}{*}{$\begin{array}{l}\text { Period } \\
\text { (years of } \\
\text { cultivation) }\end{array}$} & \multicolumn{3}{c}{ Mineral N } & \\
\cline { 2 - 4 } & \multicolumn{3}{c}{ Depth $(\mathrm{cm})$} & \\
\cline { 2 - 4 } $0-20$ & $0-15$ & \multicolumn{4}{c}{$15-40$} & $40-80$ & Total \\
\hline $20-40$ & 106 & 30 & 7 & 143 \\
$40-60$ & 47 & 11 & 5 & 53 \\
$60-80$ & 14 & 9 & 4 & 27 \\
$80-100$ & 3 & 4 & 2 & 9 \\
Contribution (\%) & 2 & 3 & 2 & 7 \\
\hline
\end{tabular}

The annual net rate of $\mathrm{N}$ mineralization was calculated from the decline of soil organic $C$ assuming fixed $C: N$ ratios for soil organic matter. microbial biomass. plant roots, and straw. Therefore. this estimate would not include mineralization from crop residues and labile microbial metabolites

Crop-crop-fallow rotation with no straw residue input during the first $50 \mathrm{yr}$ of cultivation. in lower organic matter inputs. The long-term decrease in organic matter could be larger than predicted in this study which considered a constant level of crop residue input.

The systems analysis approach helps to integrate the fragmentary knowledge of the components of soil organic matter and to develop a better understanding of the behavior of the soil system as a whole (Hillel 1977). Simulation modelling allowed testing of different input conditions, such as the rate of plant residue input and soil erosion, and studying their effects on the equilibrium level of soil organic matter. These investigations of organic matter dynamics indicate that soil erosion drastically influences the rate of organic matter depletion. However, further research is necessary to substantiate these predictions.

ALLISON, F. E. 1973. Soil organic matter and its role in crop production. Developments in soil science. 3. Elsevier, Amsterdam. 637 pp.

BAIER, W., CHAPUT, D., RUSSELO, D. and SHARP, R. 1972. Soil moisture estimator program system. Tech. Bull. No. 78, Agrometeorology Section, Agriculture Canada, Ottawa, Ont. 
BARROWS, H. L. and KILMER, V. J. 1963. Plant nutrient losses from soils by water erosion. Adv, Agron. 15: 303-316.

BIEDERBECK, V. O., CAMPBELL, C. A., BOWREN, K. E., SCHNITZER, M. and McIVER, R. N. 1980. Effect of burning cereal straw on soil properties and grain yields in Saskatchewan. Soil Sci. Soc. Amer. J. 44: 103-111.

CALDWELL, A. C., WYATT, F, A. and NEWTON, J. D. 1939. Effects of cultivation and cropping on the chemical composition of some Western Canadian prairie soils. Sci. Agric. 19: 258-270.

CAMPBELL, C. A., NICHOLAICHUK, W. and WARDER, F. G. 1977. Effect of fertilizer $\mathrm{N}$ and soil moisture on growth, $\mathrm{N}$ content, and moisture use by spring wheat. Can. J. Soil Sci. 57: 289-310. CAMPBELL, C. A., PAUL, E. A. and McGILL, W. B. 1976. Effect of cultivation and cropping on the amounts and forms of soil N. Pages 7-101 in Western Canadian Nitrogen Symposium Proceedings, Calgary, Alta.

CHATARPAUL, L., PAUL, E. A. and COLACO, W. 1980. Denitrification in Saskatchewan soils under field conditions. Proceedings ASM Annual Meeting, Miami Beach, May 1980.

CHEPIL, W. S. and WOODRUFF, N. P. 1963. The physics of wind erosion and its control. Adv. Agron. 15: $211-302$.

CHO, C. M. , CHANG, C. and KIM, Y, K. 1975. Interaction between nitrate and soil. Proc. Man. Soil Sci. Conf. Publications Branch. Manitoba Department of Agriculture, Winnipeg, Man. COUPLAND, R. T. and BRAYSHAW, T. C. 1953. The fescue grassland of Saskatchewan. Ecology 34: 386-405.

DORMAAR, J. F., PITTMAN, U. J. and SPRATT, E. D. 1979. Burning crop residues: Effect on selected soil characteristics and longterm wheat yields. Can. J. Soil Sci. 59: 79-86.

DOUGHTY, J. F., COOK, F. D. and WARDER, F. G. 1954. Effect of cultivation on the organic matter and nitrogen of Brown soils. Can. J. Agric. Sci. 34: 406-411.

GREENLAND, D. J. 1962. Soil nitrogen changes in the permanent rotation trial at the Waite Institute. Third Australian Conf. Soil Sci. Pap. No. 88, Canberra.

HALSTEAD, E. H. 1978. Soil test records. 1966-1976. In Study of methodology and development of a data base for rural land evaluation in Saskatchewan. SIP Publication, Saskatoon. Sask. HEAD, W. K. 1975. Soil map of the Termuende Farm. SIP Publ. No. M44, Saskatoon, Sask.
HENRY, J. L. 1975. The effect of management practices on subsoil nitrate levels in Saskatchewan soil. In Proceedings Soil Fertility Workshop, 1975. Saskatoon, Sask.

HILLEL, D. 1977. Computer simulation of soil water dynamics: a compendium of recent work. International Development Research Centre, Ottawa, Ont. 214 pp.

JENKINSON, D. S. and POWLSON, D. S. 1976. The effects of biocidal treatments on metabolism in soil. V. A method for measuring soil biomass. Soil Biol. Biochem. 8: 209-213.

JOHNS, L. 1971. Mass spectrometry: stable isotope assay - soils and plants. Pages 19-42 in D. A. Rennie and E. A. Paul, eds. Isotope methodology and techniques in soil-plant nutrition and plant physiology. SIP Publ. No. 76, Saskatoon. Sask.

LIPMAN, J. G. and BLAIR, A. W. 1921. Nitrogen losses under intensive cropping. Soil Sci. 12: $1-16$.

LUCAS, R. E., HOLTMAN, J. B. and CONNOR, L. J. 1977. Soil carbon dynamics and cropping practices. Agriculture and energy. Academic Press, Inc., New York.

MacDONALD, K. B., DE JONG, E. and SCHAPPERT, H. J. V. 1973. Soil physics. 1. Soil respiration. Matador Tech. Proj. Rep. No. 14, Feb. 1973. Saskatoon, Sask.

MARTEL, Y. A. and PAUL, E. A. 1974. Effects of cultivation on the organic matter of grassland soils as determined by fractionation and radiocarbon dating. Can. J. Soil Sci. 54: 419-426.

MENELEY, W. A. 1976. Hydrology of the Moose Jaw effluent irrigation area. Sask. Res. Counc. Mimeo. Rep., Saskatoon, Sask.

MOSS, H. C. 1935. Some field and laboratory studies of soil drifting in Saskatchewan. Sci. Agric. 15: 665-679.

NELSON, D. W. and SOMMERS, L. E. 1975. A rapid and accurate procedure for estimation of organic carbon in soil. Proc. Indiana Acad. Sci. 1974.84: 456-462.

NEWTON, J. D., WYATT, F. A. and BROWN, A. L. 1945. Effects of cultivation and cropping on the chemical composition of some Western Canada Prairie Province soils. Part III. Sci. Agric. 25: $718-737$.

NICHOLAICHUK, W. 1967. Comparative watershed studies in southern Saskatchewan. Trans. Amer. Soc. Agric. Eng. 10: 502-504.

NICHOLAICHUK, W. and READ, D. W. 1978. Nutrient runoff from fertilized and unfertilized fields in Western Canada. J. Environ. Qual. 7: 
542-544.

PAUL, E. A. and VAN VEEN. J. A. 1978. The use of tracers to determine the dynamic nature of organic matter. Trans. 11th Int Congr. Soil Sci. (Edmonton, Alta.) 3: 61-102.

PAUL, E. A. and VORONEY. R. P. 1980. Nutrient and energy flows through soil microbial biomass. Pages 215-237 in D. C. Ellwood et al., eds. Contemporary microbial ecology. Academic Press, London.

ROVIRA, A. D. and GREACEN, E. L. 1957. The effect of aggregate disruption on the activity of microorganisms in the soil. Aust. J. Agric. Res. 8: 659-673.

SAUERBECK, D. R. and GONZALEZ, H. A. 1977. Field decomposition of carbon-14 labelled plant residues in various soils of the Federal Republic of Germany and Costa Rica. Pages 159-170 in Proc. Symp. on Soil Organic Matter Studies, Vol. 1, Braunschweig, 1976.

SAUNDER, D. H. and GRANT, P. M. 1962. Rate of mineralization of organic matter in cultivated Rhodesian soils. Trans. Int. Soil Conf., New Zealand. pp. 235-239.

SCHEFFE, H. A. 1959. The analysis of variance. Wiley, New York.

SCHLESINGER, W. H. 1981. The world carbon pool in soil organic matter: a source of atmospheric $\mathrm{CO}_{2}$ ? In G. M. Woodwell, ed. The role of terrestrial vegetation in the global carbon cycle: Methods for appraising changes. Wiley, New York. (In press.)
SHUTT, F. T. 1925. Influence of grain growing on the nitrogen and organic matter content of the western prairie soils of Canada. Dom. of Canada, Dep. of Agric., Bull. No. 44, N.S.

SMITH, D. D. and WISCHMEIER, W. H. 1962.

Rainfall erosion. Adv. Agron. 14: 109-148.

SØRENSEN, L. H. 1975. The influence of clay on the rate of decay of amino acid metabolites synthesized in soils during decomposition of cellulose. Soil Biol. Biochem. 7: 171-177.

VAN VEEN, J. A. and PAUL, E. A. 1981. Organic carbon dynamics in grassland soils. 1. Background information and mathematical simulation. Can. J. Soil Sci. 61: 185-201.

VAN VLIET, L. J. P. and WALL, G. J. 1979. Comparison of predicted and measured sheet and rill erosion losses in southern Ontario. Can. J. Soil Sci. 59: 211-213.

WISCHMEIER, W. H., JOHNSON, C. B. and CROSS, B. V. 1971. A soil erodibility nomograph for farmland and construction sites. J. Soil Water Conserv. 26: 189-193.

WISCHMEIER, W. H. and SMITH, D. D. 1961. A universal soil-loss equation to guide conservation farm planting. Trans. 7 th Int. Congr. Soil Sci. 1960. VI 2. Madison, Wis.

WISCHMEIER, W. H. and SMITH, D. D. 1965. Predicting rainfall-erosion losses from cropland east of the Rocky Mountains. Agric. Handb. No. 282. U.S. Government Printing Office, Washington, D.C. 